\title{
Hubungan Profil Lipid (Kadar Trigliserida, HDL, LDL, Total Kolesterol) dengan Jenis Infeksi Bakteri pada Pasien Sepsis
}

\author{
Yopie Wiguna, Philia Setiawan, Prananda Surya Airlangga \\ Departemen Anestesi dan Terapi Intensif \\ Fakultas Kedokteran Universitas Airlangga RSUD Dr Soetomo Surabaya
}

\begin{abstract}
Abstrak
Gangguan profil lipid berhubungan dengan peningkatan kejadian gagal organ dan kematian pada pasien sepsis. Gangguan profil lipid mungkin berbeda antarjenis infeksi bakteri (gram positif vs gram negatif), perbedaan ini mungkin jadi disebabkan oleh perbedaan klirens endotoksin yang berbeda dan mekanisme imunologis host yang berkaitan dengan metabolism lipid. Tujuan, menganalisis perbedaan profil kadar lipid (HDL, LDL, Trigliserida, total kolesterol) dengan jenis infeksi bakteri pada pasien sepsis di ruang perawatan intensif RSUD Dr. Soetomo yang dilaksanakan pada bulan April-Juli 2020. Penelitian ini merupakan penelitian analitik observasional pada pasien dewasa yang memenuhi kritera sepsis-3. Jenis infeksi bakteri diklasifikasikan menjadi infeksi bakteri gram negatif, infeksi bakteri gram positif, infeksi campuran, dan tidak tumbuh kuman. Penelitian ini menganalisis perbedaan profil kadar lipid antarjenis infeksi bakteri menggunakan analisis normalitas data dan analisis varian data. Hasil dari 38 pasien sepsis dewasa pada penelitian ini didapatkan 13 pasien infeksi bakteri gram negatif, 13 pasien infeksi gram positif, 5 pasien infeksi campuran gram positif dan negatif, dan tidak didapatkan pertumbuhan kuman pada 7 pasien. Kadar HDL lebih rendah pada infeksi bakteri gram negatif dan infeksi bakteri campuran gram positif-gram negatif $(\mathrm{p}<0,05)$. Kadar trigliserida lebih tinggi pada infeksi bakteri gram negatif dan infeksi bakteri campuran gram positif - gram negatif $(\mathrm{p}<0,05)$. Tidak terdapat perbedaan bermakna kadar LDL dan total kolesterol antarjenis infeksi bakteri. Simpulan, kadar HDL plasma lebih rendah dan kadar trigliserida lebih tinggi pada pasien sepsis infeksi bakteri gram negatif dan bakteri campuran gram positif-gram negatif dibanding dengan pasien sepsis infeksi bakteri gram positif dan tidak didapatkan pertumbuhan kuman.
\end{abstract}

Kata Kunci: Infeksi bakteri gram negatif, infeksi bakteri gram positif, profil lipid, sepsis

\section{Relationship of Lipid Profile (Levels of Triglyceride, HDL, LDL, Total Cholesterol) with Types of Bacterial Infection in Sepsis Patients}

\begin{abstract}
Impaired lipid profiles are associated with an increased incidence of organ failure and mortality in septic patients. Disorders of the lipid profile may differ between bacterial infection types (gram-positive vs gram-negative). Differences could be due to dissimilarities in different endotoxin clearance and host immunological mechanisms related to lipid metabolism. The study analyzed differences in lipid profiles (HDL, LDL, triglycerides, total cholesterol) with the bacterial infection type in septic patients in the intensive care room of Dr. Soetomo Hospital in April-July 2020. This study was an observational analytic study of 38 adult patients who met the criteria for sepsis-3. Bacterial infection types were classified into gram-negative bacterial infections, gram-positive bacterial infections, mixed infections and culture negative. This study analyzed differences in lipid profiles between bacterial infection types, and used data normality analysis and data variant analysis. Results showed that 13 patients had gram-negative bacterial infection, 13 patients were with gram-positive infection, five patients were with mixed gram-positive gram-negative infections, and seven patients had no germ growth. Plasma HDL levels were lower in gram-negative bacterial infections and mixed gram-positive gram-negative bacterial infections $(\mathrm{p}<0.05)$. Plasma triglyceride levels were higher in gram-negative bacterial infections and mixed gram-positive gram-negative bacterial infections $(p<0.05)$. There was no significant difference in LDL levels and total plasma cholesterol between bacterial infections types. In conclusion, plasma HDL levels are significantly lower, and triglyceride levels were significantly higher in septic patients with gram-negative and mixed gram-positive bacterial infections than in sepsis patients with gram-positive bacterial infections and culture negative.
\end{abstract}

Key words: Gram-negative bacterial infection, gram-positive bacterial infection, lipid profiles, sepsis

Korespondensi: Yopie Wiguna, dr., Departemen Anestesi dan Terapi Intensif Fakultas Kedokteran Universitas Airlangga RSUD Dr Soetomo Surabaya, Jl, Jl. Mayjen Prof. Dr. Moestopo No.6-8, Airlangga, Kec. Gubeng, Kota SBY, Jawa Timur 60286 Tlp (031) 5501078, Email yopiewiguna87@gmail.com 


\section{Pendahuluan}

Sepsis didefinisikan sebagai disfungsi organ yang mengancam nyawa disebabkan oleh disregulasi respons tubuh inang terhadap infeksi. Meskipun sudah banyak kemajuan dalam bidang antibiotik dan perawatan intensif, sepsis merupakan komplikasi infeksi berat yang menjadi penyebab mortalitas utama di banyak negara. Angka mortalitas sepsis mencapai $30 \%$, sedangkan pada kasus syok sepsis dapat mencapai $80 \% .{ }^{1}$ Data dari ruang resusitasi RSUD dr Soetomo Surabaya selama tahun 2016 menunjukkan jumlah pasien sepsis mencapai 100 pasien atau $11 \%$ pasien yang masuk ke ruang resusitasi dengan mortalitas mencapai $65 \%{ }^{2}$

Produk dari dinding sel bakteri gram negatif, yaitu lipopolisakarida (LPS) dapat mencetuskan reaksi imun berat, mengarah pada sepsis dan kegagalan organ. ${ }^{3}$ Pada bakteremia gram negatif, respons inflamasi dicetuskan oleh komponen LPS dan bertindak sebagai pathogen associated molecular patterns (PAMPs). Setelah LPS berikatan dengan CD14, kaskade inflamasi dimulai. ${ }^{4}$ Penelitian Abe dkk. ${ }^{5}$ pada tahun 2010 menunjukkan bahwa sepsis akibat infeksi gram negatif menghasilkan kadar CRP plasma dan IL-6 yang lebih tinggi dibanding dengan infeksi gram positif dan secara signifikan lebih banyak pada pasien yang mengalami syok septik dengan angka mortalitas, gagal organ, dan skor APACHE II yang lebih tinggi. Pada infeksi bakteri gram positif, respons inflamasi dicetuskan oleh komponen dinding selnya mengandung lipotechoic acid dan peptidoglycan yang menimbulkan inflamasi, namun tidak sehebat LPS serta dapat pula dijumpai produksi eksotoksin yang bersifat sebagai superantigen. ${ }^{6}$

Pasien sepsis dapat mengalami gangguan profil lipid di antaranya kadar high-density lipoprotein (HDL), low-density lipoprotein (LDL), dan apolipoprotein A-I (Apo A-I) yang rendah dan kadar trigliserida (TG) yang tinggi. ${ }^{7,8,9} \mathrm{Hal}$ ini diduga karena dalam proses infeksi terjadi perubahan signifikan dalam metabolisme lipid akibat beberapa mekanisme di antaranya penurunan hidrolisis trigliserida dan lipoprotein ditambah dengan sitokin proinflamasi yang merangsang produksi asam lemak bebas dan trigliserida pada liver. ${ }^{10,11}$

Lipoprotein berperan penting dalam upaya mengikat dan menetralisir endotoksin bakteri (LPS), termasuk mengaktivasi enzim paraoxonase dan platelet-activating factor acetylhydrolase yang menginhibisi agregasi endotel dan stimulasi ekspresi endothelial nitric oxide synthase. ${ }^{12}$ HDL (termasuk apolipoprotein A1 yang terkandung di dalamnya) berperan dalam klirens endotoksin (LPS) sehingga menurunkan efek toksik bakteri. ${ }^{13,14}$ Keadaan ini memberikan petunjuk lipoprotein penting dalam mengatur fungsi kekebalan bawaan selama infeksi bakteri.

Sampai saat ini belum banyak diketahui mengenai pola gangguan lipoprotein pada sepsis dan hubungannya dengan bakteri penyebab sepsis secara spesifik (faktor patogen). Penelitian oleh Pizzini dkk. ${ }^{14}$ pada tahun 2018 menunjukkan pada pasien bakteremia tidak terdapat perbedaan profil lipid yang bermakna antara bakteremia gram negatif dan gram positif, namun penelitian ini bersifat retrospektif dan hanya menggunakan parameter HDL dan LDL. ${ }^{15}$

Penulis melaksanakan penelitian untuk menganalisis dan membandingkan profil lipid; yang terdiri atas kadar triglisedrida, HDL, LDL, dan total kolesterol; pada pasien sepsis berdasar atas jenis infeksi bakteri (gram positif atau gram negatif). Informasi yang didapatkan dari penelitian ini dapat melengkapi petunjuk mengenai pengaruh faktor patogen terhadap metabolism lipid pada sepsis.

\section{Subjek dan Metode}

Penelitian ini merupakan suatu penelitian observasional analitik menggunakan desain prospektif di ruang perawatan intensif RSUD dr Soetomo yang dilaksanakan pada bulan April-Juli 2020 yang telah mendapatkan persetujuan dari Komite Etik Rumah Sakit (Nomor 1686/KEPK/XII/2019). Kriteria inklusi pada penelitian ini adalah pasien dewasa (berusia di atas 18 tahun), memenuhi 
kriteria sepsis berdasar atas The Third International Consensus Definitions for Sepsis and Septic Shock 2016 (Sepsis-3) yang dirawat di unit perawatan intensif RSUD dr Soetomo Surabaya. Metode penelitian dijelaskan kepada wali pasien lalu bila bersedia menandatangani persetujuan (informed consent), maka pasien akan dimasukkan sebagai subjek penelitian. Kriteria eksklusi pada penelitian ini adalah pasien yang memiliki riwayat dislipidemia atau pernah mendapat pengobatan dislipidemia golongan statin atau nonstatin, atau apabila periode 1 jam sesudah time zero sepsis telah terlampaui saat dilakukan pengambilan sampel darah dan kultur. Kriteria pengeluaran adalah pasien yang tidak dapat dilakukan pengambilan spesimen darah, dahak, atau bahan biakan lain untuk pemeriksaan kultur. Time zero sepsis didefinisikan sebagai waktu dokumentasi yang sesuai dengan elemen sepsis, yaitu tanda infeksi dan kegagalan organ. Teknik pengumpulan sampel subjek penelitian menggunakan teknik total sampling. Semua subjek penelitian mendapatkan perlakuan yang sama dan tidak dilakukan alokasi kelompok. Besar sampel subjek penelitian dihitung menggunakan rumus sampel untuk uji Kohor/studi longitudinal didapatkan besar sampel penelitian minimal sejumlah 30 pasien.

Data awal seperti usia, jenis kelamin, berat

\section{Tabel 1 Demografi subjek penelitian}

\begin{tabular}{lc}
\hline \multicolumn{1}{c}{ Data Demografi } & $\mathbf{n}=\mathbf{3 8}$ \\
\hline Jenis kelamin & \\
Laki-laki & 21 \\
Perempuan & 17 \\
Usia (tahun) & \\
18-44 & 13 \\
$45-74$ & 23 \\
$>75$ & 2 \\
BMI & \\
Underweight & 2 \\
Normal & 20 \\
Overweight & 14 \\
Obesitas kelas 1 & 2 \\
\hline
\end{tabular}

dan tinggi badan, tanda vital, tanda infeksi, pengukuran nilai qSOFA dan SOFA dicatat dalam lembar pengumpulan data. Kemudian, sesuai dengan manajemen pasien sepsis, tiaptiap subjek diambil kultur darah, sputum, dan urine sebelum pemberian antibiotik dan pemeriksaan profil lipid dalam waktu satu jam setelah time zero. Hasil evaluasi klinis dan hasil kultur kuman (biasanya selesai dalam 5-7 hari) dicatat dalam lembar pengumpulan data dan selanjutnya dianalisis.

Distribusi data penelitian dilakukan uji normalitas data menggunakan Uji ShapiroWilk. Data dengan distribusi normal dianalisis menggunakan analisis varian, sedangkan data dengan distribusi tidak normal dianalisis menggunakan Uji Kruskal Wallis. Jika hasil analisis varian data menunjukkan perbedaan yang bermakna kadar profil lipid antarhasil kultur $(p<0,05)$ maka dilakukan uji ANOVA menggunakan uji LSD. Jika hasil Uji Kruskal Wallis menunjukkan perbedaan bermakna kadar profil lipid antarhasil kultur $(\mathrm{p}<0,05)$ maka dilanjutkan Uji Mann-Whitney. Analisis statistik dikerjakan dengan perangkat lunak statistical package for the social science (SPSS) v19.

\section{Hasil}

Penelitian melibatkan 38 pasien sepsis dewasa yang terbagi hampir merata antara laki-laki dan perempuan (21 vs 17 orang) dengan dominasi pasien kelompok usia 45-74 tahun, dan mayoritas memiliki BMI normal. Sebaran populasi penelitian beserta karakteristiknya dirinci dalam Tabel 1.

Beberapa karakteristik klinis pada penelitian ini dicatat dan disajikan pada Tabel 3, di antaranya hasil kultur sesuai dengan pengelompokan jenis gram, usia, jenis kelamin, indeks massa tubuh, nilai laktat, skor SOFA, skor APACHE II, dan sumber infeksi yang mendasari sepsis. Penunjang laktat dan skoring SOFA serta APACHE II merupakan parameter standar yang rutin diukur pada pasien sepsis di unit perawatan intensif RSUD Dr. Soetomo ditampilkan juga dalam Tabel 2.

Sumber infeksi tertinggi berasal dari paru 
Tabel 2 Karakteristik Klinis Antarhasil Kultur

\begin{tabular}{lccccc}
\hline & $\begin{array}{c}\text { Seluruh } \\
\text { Subjek }\end{array}$ & $\begin{array}{c}\text { Gram } \\
\text { Negatif }\end{array}$ & $\begin{array}{c}\text { Gram } \\
\text { Positif }\end{array}$ & $\begin{array}{c}\text { Gram } \\
\text { Negatif- } \\
\text { Positif }\end{array}$ & $\begin{array}{c}\text { Tidak } \\
\text { Tumbuh } \\
\text { Kuman }\end{array}$ \\
\hline Hasil pertumbuhan kuman & 38 & 13 & 13 & 5 & $7(18,4 \%)$ \\
BMI & $24,2(3,7)$ & $23(2,8)$ & $25,6(4,2)$ & $24,2(4,6)$ & $23,7(3,3)$ \\
Laktat jam 1 (mmol/L) & $2,46(1,56)$ & $2,5(1,0)$ & $2,91(2,1)$ & $1,72(0,59)$ & $2,1(1,6)$ \\
Laktat jam 6 (mmol/L) & $2,09(1,44)$ & $2,11(1,36)$ & $2,53(1,9)$ & $1,78(0,66)$ & $1,44(0,53)$ \\
APACHE II & $20(7,15)$ & $23(8,3)$ & $22(3,7)$ & $21(5,68)$ & $12(5,7)$ \\
SOFA score & $6(3,09)$ & $6(2,5)$ & $8(3,4)$ & $6(1,4)$ & $4(2,8)$ \\
Mortalitas 7 hari & 9 & 2 & 7 & 0 & 1 \\
Mortalitas 28 hari & 20 & 5 & 9 & 4 & 2 \\
Sumber infeksi & & & & & \\
Pneumonia & 24 & 9 & 8 & 4 & 3 \\
Infeksi abdomen & 9 & 4 & 2 & 1 & 2 \\
Soft tissue & 4 & 0 & 3 & 0 & 1 \\
Urologi & 1 & 0 & 0 & 0 & 1 \\
\hline
\end{tabular}

Keterangan: nilai dalam kurung pada data BMI, Laktat, APACHE II, SOFA menunjukkan simpangan baku. Sumber infeksi pada sepsis disimpulkan berdasar atas gambaran klinis pasien yang dicocokkan dengan konfirmasi hasil kultur

(pneumonia) dan didapatkan pada semua kelompok hasil kultur, diikuti dengan infeksi abdomen dan jaringan lunak. Secara terperinci dapat dilihat pada Tabel 3.

Hasil penelitian yang meliputi profil lipid (HDL, LDL, total kolesterol, trigliserida) dan hasil kultur ditampilkan pada Tabel 5. Dari 38 pasien sepsis yang dilakukan kultur, 13 subjek didapatkan pertumbuhan bakteri gram negatif, 13 subjek didapatkan pertumbuhan bakteri gram positif, 5 pasien didapati pertumbuhan bakteri campuran gram negatif dan gram positif, serta 7 subjek tidak didapatkan pertumbuhan kuman.

Hasil uji distribusi normalitas data menggunakan Uji Shapiro-Wilk menunjukkan data kadar HDL, LDL, dan total kolesterol pada semua hasil kultur serta data trigliserida pada hasil kultur gram positif dan gram negatifpositif berdistribusi normal $(p>0,05)$. Data kadar trigliserida pada hasil kultur tidak tumbuh dan gram negatif tidak berdistribusi normal $(\mathrm{p}<0,05)$. Oleh karena itu, perbedaan kadar HDL, LDL, dan total kolesterol antarhasil kultur dianalisis menggunakan analisis varian, sedangkan perbedaan trigliserida dianalisis menggunakan Uji Kruskal Wallis.

Hasil analisis varian pada data HDL menunjukkan perbedaan bermakna kadar HDL antarhasil kultur $(\mathrm{p}<0,05)$ sehingga perlu dilakukan uji lanjut ANOVA menggunakan uji LSD. Hasil uji LSD menunjukkan data kadar

Tabel 3 Hasil Pertumbuhan Organisme dari Kultur

\begin{tabular}{lccc}
\hline \multicolumn{1}{c}{ Asal Lokasi Infeksi } & Gram Negatif & Gram Positif & Gram Negatif-Positif \\
\hline Pneumonia & 9 & 8 & 4 \\
Infeksi abdomen & 4 & 2 & 1 \\
Soft tissue & 0 & 3 & 0 \\
\hline
\end{tabular}

Keterangan: asal lokasi infeksi diperkirakan dari lokasi pengambilan sampel kultur yang positif dan kondisi klinis pasien 
Tabel 4 Perbedaan Profil Lipid Antarhasil Kultur

\begin{tabular}{llccc}
\hline Profil Lipid & \multicolumn{1}{c}{ Hasil Kultur } & n & Rerata (Simp. Baku) & Nilai p \\
\hline & Tidak tumbuh & 7 & $36,86(11,63)$ & \\
Gram negatif & 13 & $19,31(6,96)$ & 0,001 \\
& Gram positif & 13 & $32,54(11,76)$ & \\
& Gram negatif, positif & 5 & $21,6(4,62)$ & \\
& Semua subjek & 38 & $27,4(11,8)$ & \\
& Tidak tumbuh & 7 & $75,43(12,63)$ & \\
& Gram negatif & 13 & $56,92(28,09)$ & \multirow{2}{*}{ Kadar LDL (mg/dL) } \\
& Gram positif & 13 & $76,62(25,89)$ & \\
& Gram negatif, positif & 5 & $66,20(8,41)$ & \\
& Semua subjek & 38 & $68,3(24,2)$ & \\
& Tidak tumbuh & 7 & $127,86(15,21)$ & \\
Kadar total kolesterol (mg/dL) & Gram negatif & 13 & $101,92(38,26)$ & 0,203 \\
& Gram positif & 13 & $125,69(35,09)$ & \\
& Gram negatif, positif & 5 & $111,60(9,76)$ & \\
& Semua subjek & 38 & $116(32,5)$ & \\
& Tidak tumbuh & 7 & $91(75-212)$ & \\
& Gram negatif & 13 & $146(90-328)$ & 0,005 \\
& Gram positif & 13 & $101(57-183)$ & \\
Kadar trigliserida (mg/dL) & Gram negatif, positif & 5 & $199(181-256)$ & \\
& Semua subjek & 38 & $146(71,1)$ & \\
& & & &
\end{tabular}

Keterangan: signifikan bila nilai $\mathrm{p}<0,05$

HDL pada hasil kultur tidak tumbuh lebih tinggi nilainya dibanding dengan hasil kultur gram negatif dan campuran gram positif-gram negatif; data HDL hasil kultur gram positif lebih tinggi nilainya dibanding dengan hasil kultur campuran gram positif-gram negatif. Hasil analisis varian pada data LDL menunjukkan tidak terdapat perbedaan bermakna kadar

Tabel 5 Perbedaan Profil Lipid antara Gram Negatif dan Positif

\begin{tabular}{llccc}
\hline \multicolumn{1}{c}{ Profil Lipid } & Hasil Kultur & $\mathbf{n}$ & Rerata (Simp. Baku) & Nilai p \\
\hline \multirow{2}{*}{ Kadar HDL (mg/dL) } & Gram negatif & 13 & $19,31(6,96)$ & \multirow{2}{*}{0,002} \\
& Gram positif & 13 & $32,54(11,76)$ & \\
\multirow{2}{*}{ Kadar LDL (mg/dL) } & Gram negatif & 13 & $56,92(28,09)$ & 0,075 \\
\multirow{2}{*}{ Kadar total kolesterol (mg/dl) } & Gram positif & 13 & $76,62(25,89)$ & \\
& Gram negatif & 13 & $101,92(38,26)$ & \multirow{2}{*}{0,112} \\
Kadar trigliserida (mg/dl) & Gram positif & 13 & $125,69(35,09)$ & \\
& Gram negatif & 13 & $146(90-328)$ & \multirow{2}{*}{0,013} \\
\hline
\end{tabular}

Keterangan: signifikan bila nilai $\mathrm{p}<0,05$ 
LDL antar hasil kultur ( $p>0,05)$, Hasil analisis varian pada data kolesterol total menunjukkan tidak terdapat perbedaan bermakna kadar kolesterol total antarhasil kultur ( $p>0,05$; Tabel 4).

Hasil uji Kruskal Wallis pada data trigliserida menunjukkan perbedaan yang bermakna kadar trigliserida antarhasil kultur $(\mathrm{p}<0,05)$ sehingga perlu dilakukan uji lanjut untuk mengetahui mana yang berbeda menggunakan Uji Mann Whitney. Hasil Uji Mann Whitney menunjukkan kadar trigliserida pada hasil kultur tidak tumbuh lebih rendah secara bermakna dibanding dengan hasil kultur gram negatif-gram positif. Kadar trigliserida pada hasil kultur gram negatif lebih tinggi dibanding gram positif. Kadar trigliserida pada hasil kultur gram positif lebih rendah bermakna dibanding hasil kultur campuran gram positif-gram negatif.

Hasil uji t dua sampel bebas menunjukkan perbedaan bermakna kadar HDL antara hasil kultur gram negatif dan positif $(p<0,05)$, serta tidak terdapat perbedaan bermakna kadar LDL dan kolesterol total antara hasil kultur gram negatif dan positif $(p>0,05)$. Hasil Uji Mann Whitney menunjukkan perbedaan bermakna kadar trigliserida antara hasil kultur gram negatif dan positif $(\mathrm{p}<0,05)$.

\section{Pembahasan}

Lipoprotein diketahui terlibat dan memainkan peranan dalam imunitas dan proses infeksi. Perubahan komposisi dan konsentrasi pada profil lipid dan lipoprotein diketahui terjadi pada pasien sakit kritis utamanya sepsis. ${ }^{8,16}$ Studi menunjukkan bahwa terdapat penurunan kadar HDL pada pasien sepsis berat. Penelitian yang dilakukan Jung-Yien dkk. ${ }^{17}$ menunjukkan bahwa kadar HDL yang rendah pada hari pertama sepsis berat berhubungan dengan peningkatan mortalitas dan luaran klinis yang lebih buruk. Organisme penyebab sepsis yang diidentifikasi melalui kultur juga diketahui mencetuskan respons inflamasi yang lebih berat dibanding dengan bakteremia yang disebabkan oleh organisme gram positif. ${ }^{5}$
Secara rerata pada pasien sepsis yang menjadi subjek penelitian ini, didapatkan kadar HDL rerata yang rendah, yaitu 27,4 $\mathrm{mg} / \mathrm{dL}$ dengan simpangan baku 11,8 mg/ dL. Sementara, kadar trigliserida didapatkan cenderung tinggi dengan rerata $146,9 \mathrm{mg} /$ dL dengan simpangan baku $71,1 \mathrm{mg} / \mathrm{dL}$. Sementara itu, untuk kadar LDL didapatkan rerata $68,3 \mathrm{mg} / \mathrm{dL}$ dan kadar kolesterol total rerata $116,1 \mathrm{mg} / \mathrm{dL}$ yang masih tergolong rentang normal. Hasil yang didapatkan ini sesuai dengan beberapa penelitian lain bahwa pasien sepsis akan cenderung memiliki kadal HDL rendah dan trigliserida tinggi. 8 , 18, 19

Pada penelitian ini kadar plasma HDL pada pasien sepsis dengan hasil kultur gram negatif lebih rendah dibanding dengan kadar plasma HDL pada pasien sepsis dengan hasil kultur gram positif $(19,31 \mathrm{mg} / \mathrm{dL}$ dibanding dengan $32,54 \mathrm{mg} / \mathrm{dL}$ ). Kadar plasma HDL pada pasien dengan hasil kultur gram positif lebih tinggi (32,54 mg/dL dibanding dengan $21,6 \mathrm{mg} / \mathrm{dL})$ dibanding dengan kadar plasma HDL pada pasien sepsis dengan hasil kultur campuran gram positif-gram negatif. Perbedaan ini bermakna secara statistik $(p=0,001)$.

Beberapa penelitian meneliti perubahan lipoprotein pada sepsis dalam kaitannya dengan jenis organisme penyebab sepsis. Penelitian oleh Guoying dkk. ${ }^{25}$ mengikuti perubahan profil lipid pada pasien sejak dari tahap infeksi local, SIRS dan berlanjut menuju sepsis. Penelitian Guoying dkk. ${ }^{25}$ menunjukkan bahwa kadar HDL dan Apo-B cenderung mengalami penurunan pada saat pasien mengalam sepsis dan penurunan ini lebih signifikan pada pasien sepsis gram negatif bila dibanding dengan sepsis gram positif.

Penelitian Black dkk. ${ }^{19}$ tahun 2020 pada 171 pasien sepsis menunjukkan bahwa penurunan kadar kolesterol total, HDL dan LDL terjadi secara bermakna pada pasien sepsis yang didapatkan pertumbuhan kuman dibanding dengan pasien sepsis yang tidak didapatkan pertumbuhan kuman dan besarnya penurunan kadar HDL lebih besar pada populasi dengan hasil kultur gram negatif.

LPS adalah endotoksin yang menyusun 
membran luar bakteri gram-negatif. Setelah dilepaskan dalam darah pada saat reproduksi sel, lisis, atau kematian bakteri, lipid A bagian terpenting dari LPS menginduksi respons inflamasi. Hal ini dimediasi oleh sitokin proinflamasi yang dilepaskan terutama dari monosit/makrofag dan neutrofil, seperti tumor necrosis factor- $\alpha$ (TNF- $\alpha$ ), interleukin$1 \beta$ (IL-1 $\beta$ ), dan interleukin-6 (IL-6). ${ }^{21}$ Untuk mencegah respons inflamasi yang berlebihan, sistem imun inang telah mengembangkan beberapa mekanisme kontrol termasuk membentuk LPS binding protein (LBP). HDL, serta lipoprotein plasma lainnya (LDL, lipoprotein kaya TG) dapat mengikat dan menetralkan LPS bakteri gram-negatif serta asam lipoteikoat bakteri gram-positif (LTA). ${ }^{22}$ Vitalnya peran HDL dalam bersihan LPS terutama pada infeksi gram negatif mungkin dapat menjelaskan kadar HDL lebih rendah dalam plasma pada pasien sepsis yang disebabkan oleh infeksi gram negatif pada penelitian ini.

Hasil analisis varian pada data LDL menunjukkan kadar LDL pada pasien dengan pertumbuhan kultur gram negatif lebih rendah dibanding dengan pada pasien dengan hasil kultur lainnya, namun perbedaan ini tidak bermakna secara statistik $(p>0,05)$. Penelitian Black dkk. ${ }^{19}$ menunjukkan bahwa kadar LDL inisial yang rendah pada pasien sepsis menunjukkan peluang pertumbuhan kultur yang lebih tinggi pada pasien sepsis karena setiap penurunan $1 \mathrm{mg} / \mathrm{dL}$ kadar plasma LDL meningkatkan kemungkinan tumbuhnya kultur sebesar 2,5\%. Kadar plasma LDL juga secara bermakna lebih rendah pada bakteremia yang disebabkan oleh organisme gram negatif dibanding dengan organisme gram positif. Hasil ini serupa dengan penelitian kami, namun kemaknaan statistik yang tidak tercapai pada penelitian kami mungkin disebabkan oleh jumlah subjek penelitian yang lebih kecil dan pengambilan sampel darah yang dilakukan hanya pada jam pertama setelah time zero.

Penelitian ini menunjukkan perbedaan bermakna kadar trigliserida plasma yang lebih tinggi pada subjek hasil kultur gram negatif dan campuran gram positif-gram negatif dibanding dengan subjek hasil kultur gram positif dan tidak didapatkan pertumbuhan kultur. Hasil yang didapatkan sesuai dengan penelitian sebelumnya oleh Black dkk. ${ }^{19}$ yang mendapatkan bahwa kadar trigliserida pada jam ke-48 secara bermakna lebih tinggi pada pasien sepsis gram negatif dibanding dengan sepsis gram positif. Hasil penelitian oleh Feng dkk. ${ }^{22}$ juga menunjukkan bahwa kadar trigliserida yang tinggi berkorelasi dengan skor SOFA dan mortalitas yang lebih buruk pada pasien sepsis.

Hipertrigliseridamia sering didapatkan pada subjek yang menderita infeksi dan inflamasi, contohnya pada pasien dengan AIDS, SLE, dan cystic fibrosis. Hal ini dikaitkan dengan kadar IL-6 dan TNF alfa yang tinggi pada pasien tersebut. ${ }^{24}$ Hipertrigliseridaemia pada pasien yang mengalami inflamasi dihubungkan dengan peningkatan produksi lipoprotein dan klirens lipoprotein yang menurun. Peningkatan produksi partikel kaya TG merupakan efek sekunder re-esterifikasi dari asam lemak plasma yang berasal dari peningkatan lipolisis dan sintesis asam lemak pada liver. Peningkatan lipolisis menyebabkan flux asam lemak bebas ke dalam liver dan mempromosikan sekresi VLDL. Peningkatan lipolisis dimediasi oleh faktor hormonal dan non-hormonal. ${ }^{25}$

Hasil plasma total kolesterol pada penelitian ini didapati lebih rendah pada pasien dengan hasil kultur gram negatif dibanding dengan hasil kultur lainnya, namun perbedaan ini tidak bermakna secara statistik. Hal ini mungkin disebabkan oleh dalam plasma total kolesterol terdapat banyak komponen seperti HDL, LDL, VLDL, apolipoprotein lainnya yang tidak diteliti pada penelitian ini.

Pada penelitian ini didapatkan 5 pasien dengan hasil kultur pertumbuhan campuran gram positif-gram-positif. Jika diamati lebih lanjut dari kelima pasien tersebut, dua pasien didapatkan pertumbuhan Acinetobacter baumani (gram-negatif) pada lebih dari satu lokasi, yaitu darah kanan, darah kiri dan aspirat ETT, satu pasien didapatkan pertumbuhan kuman E. coli dan Enterobacter sp. pada lebih 
dari satu lokasi. Hal ini menjelaskan bahwa pada kelompok hasil kultur campuran ini pola profil lipid mendekati kelompok kultur gramnegatif.

\section{Simpulan}

Kadar HDL plasma lebih rendah dan kadar trigliserida lebih tinggi pada pasien sepsis dengan infeksi bakteri gram negatif dan bakteri campuran gram negatif dan positif dibanding dengan pasien sepsis dengan infeksi bakteri gram positif dan tidak didapatkan pertumbuhan kuman. Tidak didapatkan perbedaan kadar LDL dan kolesterol total plasma pada pasien sepsis antarjenis infeksi bakteri.

\section{Daftar Pustaka}

1. Jawad IL, Luksic I, Rafnsson SB. Assessing available information on the burden of sepsis: Global estimates of incidence, prevalence and mortality. J Glob Health. 2012;2(1):010404.

2. Data Internal RSUD dr. Soetomo. Data ruang resusitasi. Surabaya: RSUD dr. Soetomo; 2016.

3. Angus DC, Poll TV. Severe sepsis and septic shock. New Eng J Med. 2013;369:840-51.

4. Lee SH, Park MS, Park BH, Jung WJ, Lee IS, Kim SY, dkk. Prognostic implications of serum lipid metabolism over time during sepsis. Biomed Res Int. 2015;2015:789298.

5. Abe R, Oda S, Sadahiro T, Nakamura M, Hirayama Y, Tateishi Y, dkk. Gram negative bacteremia induces grreater magnitude of inflammatory response than gram positif bacteremia. Crit Care. 2010;14(2):R27.

6. Wang JE, Dahle MK, McDonald M, Foster SJ, Aasen AO, Thiemermann C. Peptidoglycan and lipothecoic acid in gram positive bacterial sepsis: receptors, signal transduction, biological effects, and synergism. Shock. 2003;20(5):402-14.

7. Cirstea M, Walley KR, Russell JA, Brunham LR, Genga KR, Boyd JH. Decreased highdensity lipoprotein cholesterol level is an early prognostic marker for organ dysfunction and death in patients with suspected sepsis. J Crit Care. 2017;38:28994.

8. Zou G, He J, Ren B, Xu F, Xu G, Zhang W. The delta high-density lipoprotein cholesterol ratio; a novel parameter for gram negative sepsis. Springerplus. 2016;5(1):1044.

9. Khovidhunkit W, Kim MS, Memon RA, Shigenaga JK, Moser AH, Feingold KR, dkk. Effects of infection and inflammation on lipid and lipoprotein metabolism: mechanism and consequences to the host. J Lipid Res. 2004;45(7):1169-96.

10. Barcia MA, Harris HW. Triglyceride-rich lipoproteins as agents of innate immunity. Oxford J. 2005:41(Suppl 7):498-503.

11. Eichbaum EB, Harris HW, Kane JP, Rapp JH. Chylomicron can inhibit endotoxin activity in vitro. J Surg Res. 1991;51(5):413-6.

12. Thaveeratitham $P$, Plengpnich $W$, Naen Udom W, Patumraj S, Khovidhunkit W. Effects of human apolipoprotein A-I on endotoxin-induced leukocyte adhesion on endothelial cells in vivo and on the growth of Escherichia coli in vitro. J Endotox Res. 2007;13:58-64.

13. Walley KR, Francis GA, Opal SM, Stein EA, Russell JA, Boyd JH. The central role of proprotein convertase subtisilin/kexin type 9 in septic pathogen lipid transport and clearance. Am J Respir Crit Care Med. 2015;192(11):1275-86.

14. Pizzini A, Kurz K, Orth-Hoeller D, Fille M, Rabensteiner J, Lunger F. The impact of bacteremia on lipoprotein concentrations and patient's outcome: a retrospective analysis. Eur J Clin Microbiol Infect Dis. 2019;38(7):1279-86.

15. Colangiulo A, Angelini L, Gallerani M, Zuliani G, Gazzola K. Serum lipid profile and survival in patients with sepsis. Nutrit Metabolism Cardiovasc Dis. 2017;27(1):15.

16. Leeuwen HJV, Heezius ECJ, Dallinga GM, Strijp JAG, Verhoef J, Kessel KPM. Lipoprotein metabolism in patients with severe sepsis. Crit Care Med. 2003;31(5):1359-66.

17. Jung-Yien C, Jih-Shuin J, Chong-Jen Y, Pan- 
CHyr Y. Low serum level of high-density lipoprotein cholesterol is a poor prognostic factoir for severe sepsis. Crit Care Med. 2005;33(8):1688-93.

18. Pizzini A, Kurz K, Orth-Hoeller D, Fille M, Rabensteiner J, Lunger F, dkk. The impact of bacteremia on lipoprotein concentrations and patient's outcome: a retrospective analysis. Eur J Clin Microbiol Infect Dis. 2019;38(7):1279-86.

19. Black LP, Puskarich MA, Henson M, Miller T, Reddy ST, Fernandez R, dkk. Quantitative and qualitative assessments of cholesterol association with bacterial infection type in sepsis and septic shock. J Intensive Care Med. 2020;885066620931473.

20. Pirillo A, Catapano AL, Norata GD. HDL in Infectious disease and sepsis. Dalam: Barrett JE, Flockerzi V, Frohman MA, Geppetti P, Hofmann FB Michel MC, dkk. penyunting. Handbook of experimental pharmacology. Switzerland: Springer; 2015. hlm. 485-500.

21. Grunfeld C, Marshall M, Shigenaga JK, Moser AH, Tobias P, Feingold KR. Lipoproteins inhibit macrophage actication by lipothecoic acid. J Lipid Res. 1999;40(2):245-52.

22. Feng QP, Wei QW, Chaugai S. Cholesterol levels and risk for sepsis among patients admitted to the hospital with infection. JAMA Network. 2019;2(1):e187223.

23. Esteve E, Ricart W, Fernandez-Real JM. Dyslipidemia and inflammation; an evolutionary conserved mechanism. Clin Nutrit. 2005;24:16-31.

24. Memon R, Grunfeld C, Moser A, Feingold K. Tumor necrosis factor mediates the effects of endotoxin on cholesterol and triglyceride metabolism in mice. Endocrinology. 1993;132:2246-53. 